\title{
The Implementation of Buen Vivir in Ecuador: An Analysis of the Stakeholders' Discourses
}

\author{
Lucile Marchand $^{1}$ and Mathilde Hérault ${ }^{2}$
}

\begin{abstract}
Buen vivir is a central notion in Ecuador and was introduced in its Constitution in 2008. On the individual level, this notion describes a multidimensional form of well-being, integrating strong cultural and ecological aspects based on indigenous communities' knowledge. On the national scale, buen vivir is the key notion of public policies and justifies an intervention of the state in all dimensions of sustainable development. The implementation of buen vivir in a developing country as Ecuador raises questions about multiple social and economic aspects. The aim of this paper is to identify all of these challenges that such a transition implies. To do so, this paper uses a qualitative and multidimensional approach based on 40 semi-directive interviews with stakeholders of the policy implementation of buen vivir. The interview grid was divided into four parts: (i) individual characteristics, (ii) definition and implementation of buen vivir, (iii) the extractivism in Ecuador and (iv) the challenges of the transition between two models of development. The preliminary results identify two major challenges. Firstly, the main challenge is the governance of this major transition and the issue of corruption in Ecuador. Secondly, these interviews show that education is the most central dimension to implement buen vivir correctly.
\end{abstract}

Keywords: Buen vivir, discourse's analysis, extractivism

\section{Introduction}

The sustainable development literature is enriched by proposals from the South. The latter discuss the relevance of this notion from the Bruntland Report of 1987, like the buen vivir in South America (Khotari et al., 2014). These proposals specify and bring some singularity to the literature of sustainable development from northern countries often described as too broad and not adapted to the specificities of the South.

Buen vivir is a complex notion that translates a term from South American indigenous communities. Originally, it describes a state of well-being and wholeness of an individual and the community, in harmony with their natural and social environment (Huanacuni, 2010). Paradoxically, it is a concept both broad and singular. Broad, because the buen vivir takes into account a multitude of determinants impacting the happiness of an individual; characteristics that are, material and immaterial, objective and subjective. Singular, because it is rooted in indigenous cultures and breaks with the "eurocentric universalism" (Beling et al., 2018). Its popularization, initially through indigenous social movements and then through its institutionalization, contributed to a flourishing literature attempting to define and formalize it (Vanhulst and Beling, 2014, Le Quang, 2017). The different interpretations of the notion are linked to different readings and translations, but also to different social and environmental demands that have emerged over the last thirty years (Fontaine 2004, Vanhulst and Beling 2014, Le Quang 2017). Indeed, Vanhulst and Beling (2014) explain the institutionalization of the concept by the convergence of three social movements: (i) the struggles of indigenous communities for the preservation of 
territories from natural resource extraction policies (ii) the alterglobalists movements against global warming and social exclusion and (iii) excluded from development.

Thus, the notion of buen vivir enriches development and environmental economics in several aspects. At the individual level, it justifies the necessary exit from a purely quantitative and individualistic vision of well-being. Due to its strong spiritual and community dimensions, buen vivir sheds light on new elements. In addition, the relationship between communities and their natural environment discusses the relevance of a monetary valuation of nature found in standard economy models. At the macroeconomic level, as the buen vivir has been institutionalized fortifies discussions on several key themes. First, the Ecuadorian experience is likely to offer new elements to appreciate the (neo-)structuralist public policies that base economic development on state interventionism. Secondly, the implementation of buen vivir implies the exit from extractivism evoking both the natural resources management literature as well as the issue of the financing of public policies.

Beyond these theoretical contributions, this article focuses more specifically on the operationalization of buen vivir in Ecuador. This concept has been at the heart of public policies since the end of the 2000s. The study of the practical application can sweep away all the challenges of sustainable development: from the singularity of the model to the difficult combination of social and environmental concerns. Thus, the transition from a rent-based economy to a buen vivir economy implies profound socio-economic and institutional changes. Based on textual analysis of 40 semi-structured interviews, this article aims to define them. In other words, we seek to understand what Ecuador has to gain or lose by implementing buen vivir. For this, we will discuss the challenges that have been defined or suggested in the scientific literature. Then, we will focus on the representations of the stakeholder transition issues of buen vivir.

\section{Literature Review}

The buen vivir approaches are synthesized in the works of Le-Quang and Vercoutere (2013) and those of Hidalgo-Capitán, Cubillo and Guevara (2014). The authors define two typologies whose boundaries are substantially similar. Villalba and Etxano (2017) group them together in the same table that we present below.

Table 1: Differential elements of the three currents concerning buen vivir

\begin{tabular}{|c|c|c|c|}
\hline & Indigenous/Culturalist & Ecologist/Post-developmentalist & Socialist-statists/Eco-Marxist \\
\hline Epistemology & Ancestral Andean-Amazonian cosmovision & Post-modern & Modern \\
\hline \multirow[t]{3}{*}{ Terminology } & Sumak kansay & Buen Vivir & Buen vivir \\
\hline & Buen convivir (to coexist well) & & Well-being \\
\hline & & & Human development \\
\hline \multirow[t]{2}{*}{ Priorities } & Andean cosmovision (identity and spirituality & Preservation of nature & Recovery of the state \\
\hline & Communities ( self-government /autonomy & Localized social emancipation & Equity and social justice \\
\hline Nature & Widened living community & $\begin{array}{l}\text { Biocentrism } \\
\text { Strong sustainability }\end{array}$ & $\begin{array}{l}\text { Tactic/pragmatic (weak) } \\
\text { sustainability }\end{array}$ \\
\hline $\begin{array}{l}\text { Relation with } \\
\text { Development }\end{array}$ & Alternative to development & Alternative to development & Neo-developmentalism \\
\hline Principal agent & Peoples and nationalities & Society & State \\
\hline Strategies & Communitarian (re)construction & $\begin{array}{l}\text { Post-extractivism } \\
\text { Collective and participatory } \\
\text { transitions }\end{array}$ & $\begin{array}{l}\text { Transformation of the productive } \\
\text { matrix } \\
\text { Endogenous accumulation } \\
\text { Public management }\end{array}$ \\
\hline
\end{tabular}

Source: Villalba and Etxano (2017) based on Le-Quang and Vercoutere (2013) and Hidalgo-Capitán, Cubillo and Guevara (2014). 
The culturalist approach is based on the practices and beliefs of indigenous communities that prevailed before colonization. The buen vivir would be the Spanish translation of a multidimensional state of well-being spiritually impregnated in all these communities and disrupts the Western vision (Viteri Gualinga, 2002). The frame of thought is holistic, that is, this vision of well-being is global and can't be broken down into disconnected dimensions (Viteri Gualinga, 2002). Methodological holism also implies a collective vision of well-being. An individual could not consider his happiness independently of others' and could not ignore the consequences of his actions on others. This collective vision also includes nature itself, which is sacred and that individuals seek to protect. As indicated in Table 1, the priority of this approach is the recognition of cultural specificities but also the autonomy of the territories on which these communities live which justify the strategy of community (re)building (Cubillo-Guevara, 2016). The challenge for these communities is to defend their natural environment regarding the extraction of natural resources. This was the heart of the indigenous social movements that began in the late 1980s and marks the beginning of the popularization of the concept of buen vivir (Fontaine, 2008).

The multiplicity of socio-environmental conflicts over the period has allowed the convergence of indigenous and ecological social movements (Fontaine, 2008). The literature implies similarities between the culturalist and ecologist approach of buen vivir. They are defined as post-developmentalist because of the negative social and environmental externalities that development implies. This approach of buen vivir attempts to extend the culturalist vision of society to the whole society (Acosta and Gudynas, 2011, Acosta and Martinez, 2011, Acosta, 2014). Thus, the priorities defined in the approach are the preservation of nature and political and social inclusion. Gudynas (2011e) considers the development of the notion of superfuerte sustainability to make possible the integration of buen vivir in the debate of weak/strong sustainability that opposes the orthodox and heterodox thesis in economics. From a policy standpoint, this means the development of a biocentric, social and solidarity-based economy based on a participatory political system. With regard to these points, the border between buen vivir and degrowth is thin. The scientific literature assimilates them as post-developmental currents (Gudynas, 2011c, Vanhulst and Beling, 2013, 2014, Kothari et al., 2014, Beling et al., 2018); or builds on the work of decay to define the buen vivir model proposal (Acosta, 2014). The distinction exists and is the fact, firstly, of the community origins of buen vivir in opposition to the European theoretical origins of degrowth. Secondly, the delicate reduction of the level of consumption and production that degrowth can defend appears to be socially inapplicable in a developing country (Gudynas, 2011a, 2011b, 2011c, 2011d).

Finally, the social-statist approach reflects, in turn, the attempt to implement buen vivir in Ecuador, which is centered on government, diversification and redistribution policies defined in the national plans. The Ecuadorian government does not reject development but the means that have been implemented so far for development (SENPLADES, 2009, 2019). The notion of well-being described in the planning plans is more a reflection of the application of the basic needs approach by referring to "buen vivir rights" which can take the form of "right of access" to the first need goods (healthy food, drinking water, ...) (Streeten et al., 1981, Stewart, 1985, Constitution of Ecuador, 2008, Senplades, 2013). According to the literature, it represents an alternative development rather than a real alternative. 
Drawing the conceptual contours of these three approaches is the main objective of the buen vivir literature (Guardiola et al., 2014). In parallel, the literature highlights the important gap between the definition and the origins of buen vivir and the application of the latter by the Ecuadorian government. The differences are of several kinds and mark the main break points between the approaches: very limited economic diversification (Villalba and Etxano, 2017), the increasing institutional verticality (Walsh, 2010, 2012, Radcliffe, 2012), the multiplicity of socio-environmental conflicts and the violence of repressions (Arsel et al., 2016).

In spite of the richness of the discussions making sure to draw the conceptual contours of buen vivir, we wish to concentrate on the operationalization of the national project. For this, we base ourselves on the main common point of these three approaches: the will to leave a model of development based on the extraction of the petroleum resources. Of course, the time horizons of the exit from the extractivism are different depending on the approaches. The culturalist and ecological proposals point out the importance of stopping the extraction of natural resources as quickly as possible, especially in protected areas (Larrea, 2013). The socialist-statist approach justifies the extraction of oil in the medium term to reach the buen vivir in the long term (Senplades, 2009, 2013).

The definition of the issues of the exit of extractivism involves the study of the consequences and the impacts of the oil extraction on the economy and the development of the country. The literature on the natural resource curse can help us to understand the relationship between natural resource endowments and growth and / or development. The notion of a curse means that this relationship is negative. The endowment of natural resources is a brake for development and growth (Sachs and Warner, 1995). The literature also focuses on defining the different transmission channels that explain this negative relationship. Briefly, the explanatory channels can be economic as well as institutional. On the economic level, the concept of Dutch disease contributes to the accentuation of the imbalance of the productive structure (Corden, 1984). The presence of a natural resource subject to rent intensifies this imbalance as it skews incentives (Ebeke, et al., 2015). At the institutional level, the literature defines a negative relationship between institutional quality and natural resource endowment through corruption and rent-seeking behavior around the rent, as well as non-efficient public spending often represented by the notion of "white elephants" (Robinson and Torvik 2005). The political channel also explains a negative relationship between natural endowments and several development indicators according to Bulte and al. (2005). Endowment does not necessarily imply more redistribution in the education sectors (Gylfason, 2001). Nevertheless, more recent work challenges the consensus that has been established in two ways. On the one hand, Ross (2001) and Stijns (2005) establish a positive relationship between rent-holding and the degree of redistribution of public revenues in health and education. On the other hand, work is being done to discuss the relevance of econometric models and point out that, on a particular scale, it is possible to detect positive effects (Van Der Ploeg, 2011, Van Der Ploeg and Poelhekke, 2016).

The literature combining the theme of natural resources and socio-economic performance in Ecuador is less developed. The benefits of the oil sector accounted for 29\% of government revenue over the period 2000-2012 (Larrea, 2013). As the literature on the curse of natural resources, the issues of extractivism are multidimensional. The 
main public policy challenge of buen vivir is the diversification of the productive structure (SENPLADES, 2009, 2013). The plans describe the transition from a structure based on the export of natural resources to an economy of knowledge, biotechnology and the valorization of biodiversity (SENPLADES, 2009, 2013). To do this, the Ecuadorian government justifies the oil exploitation to finance the transition. Although the time horizon of our study is still short to measure the results of buen vivir policies, the literature highlights a greater reliance to natural resources than at the beginnings of economic diversification process a decade ago (Larrea, 2013, Arcel et al 2016, Purcell et al, 2016). This setback is nevertheless offset by social improvements in terms of poverty, inequalities in education and health. These are linked to a greater public commitment in these areas (Ponce and Vos, 2012, Larrea, 2013).

These elements echo the work of Arcel et al. (2016) who study the "extractive imperative" that particularly affects the Latin American socialist countries (Argentina, Venezuela, Ecuador, Bolivia). This notion refers to the dependence of social policies on the extraction of mineral and oil natural resources. The extraction would be seen as the financing of the Big Push of the Rostow model (Rostow, 1959). The authors observe that three factors create this dependence: the high rate of commodity prices, the massive Chinese investment in the region and in these sectors, as well as the development of bureaucracy. The paper also mentions the difficulty of defining a coherent and singular development model as well as the difficulty of the State and its institutions to apprehend this model of development. "The extractive imperative" is also studied in Van Teijlingen's article (2016), which, based on qualitative interviews, shows the impact of the political discourse justifying the extraction on the individuals mainly concerned locally. In this same line, the works of Purcell et al. (2016) underline, through a Marxist political economy analysis, the underestimation of the effects of dependence on natural resources in the work of CEPAL (2012) on which the South American economies, including Ecuador. The authors add that dependence on natural resources leads to structural institutional specificities in the process of accumulation.

\section{Methodology}

The research questions are based on the representations made by the Ecuadorian population on the buen vivir, the formal institutions and the obstacles to the implementation of the project. These elements justify a qualitative approach for several reasons. Firstly, the formalization of buen vivir is made difficult by the polysemous and subjective nature of the notion. To approach this subject in a quantitative way would imply to set aside of important subjective elements. Secondly, the reading of the national plans as well as the scientific articles highlighting the inconsistencies of the public policies implemented. For this, we do not believe that the quantitative approach is the most appropriate one because the data are limited and do not make possible to specify the institutional stakes. The objective of the qualitative approach is to try to identify mechanisms that structure the social contract established between the government and the Ecuadorian people and to distinguish between political discourse and actual public policies. Finally, the subject evokes a holistic approach that can't be studied taking into account of a single dimension and a single discipline in the social sciences. Face to face 
interviews will allow us to shed light on these interconnections and thus help us to draw an overall vision of the transition from an extractive economy to buen vivir in Ecuador. The choice of semi-directivity is justified by the degree of knowledge and complexity of the subject studied (Berthier, 2000, Huntington 2000). Although the scientific literature is rich for such a recent subject, the number of empirical articles or articles dealing with the operationalization of buen vivir is low. Therefore, we start from the premise that our knowledge on the subject is partial. As a result, directive interviews might omit some of the information (Fenneteau, 2001). The non-directive interview is not appropriate either because our subject is based on the representations of the stakeholders of the buen vivir and not on an intimate and personal subject that would require putting the interviewee particularly at ease.

In a first stage the interview was based on basic socio-demographic characteristics: age, gender, marital status and occupation. We completed this by asking whether the respondent was a member of an association or political party, which would have revealed a specific degree of involvement in one or more dimensions of buen vivir. Then we continued on the professional trajectory of the interviewees. It allowed us to better know and understand the profile and to see if the representations of the respondents are not the result of past professional experience. It also allows us to see if the level of expertise of the individual can be enriched by previous professional experiences. Career trajectories divided by professional retraining can sometimes involve unexpected maintenance trajectories rich in new information. In a second step, the interview focused on buen vivir. The objective was to understand how individuals embrace the notion of buen vivir and how it was daily translated in order to confront their vision with the elements of literature mentioned earlier or with the implementation of buen vivir by the Ecuadorian government. Thirdly, and this part of the interview was the hardest for the interviewees, we tried to highlight representations of the oil sector in Ecuador. Through this theme we could see how the dependence on the oil sector could have repercussions on the representations of individuals or highlight the links of dependence between the oil sector and the service or professional environment in which the interviewee practices. Finally, we finished the interview on the issues of the implementation of the buen vivir that the interviewees defined as the most important. The question was formulated in two different ways so as to obtain the maximum of information.

We conducted nearly 40 interviews between September and December 2017. Their duration ranged from 30 minutes to 2 hours depending on availability and the interest of the respondent. The choice of individuals is based on their professional, associative and union profile. Table 2, presented below, describes these different profiles

\begin{tabular}{|c|c|c|c|c|c|}
\hline Variables & & & Modalities & & \\
\hline Gender & Men $\quad(60 \%)$ & Women $(40 \%)$ & & & \\
\hline Age group & $18-30(12,5 \%)$ & $30-40(12,5 \%)$ & $40-50(45 \%)$ & 50 and older $(30 \%)$ & \\
\hline Profesionnal Status & Private $(45 \%)$ & $\begin{array}{l}\text { Public } \\
(55 \%)\end{array}$ & & & \\
\hline $\begin{array}{l}\text { Dimension of buen } \\
\text { vivir }\end{array}$ & $\begin{array}{c}\text { Political } \\
(15 \%)\end{array}$ & $\begin{array}{c}\text { Économic } \\
(27,5 \%)\end{array}$ & $\begin{array}{l}\text { Social } \\
(20 \%)\end{array}$ & $\begin{array}{l}\text { Cultural } \\
(20 \%)\end{array}$ & $\begin{array}{c}\text { Ecological } \\
(17,5 \%)\end{array}$ \\
\hline Profile & $\begin{array}{c}\text { Decision-makers } \\
(17,5 \%)\end{array}$ & $\begin{array}{c}\text { Researchers } \\
(17,5 \%)\end{array}$ & $\begin{array}{c}\text { Associations/Unions } \\
(22,5 \%)\end{array}$ & Companies $(17,5 \%)$ & $\begin{array}{l}\text { Political Parties } \\
\qquad(10 \%)\end{array}$ \\
\hline
\end{tabular}




\section{Results}

The reading of the interviews tells us about the structure of representations of the public policies of buen vivir. We will present here the passages of the interviews that we consider the most relevant for our research question. We make the choice to resume the interview grid and present these elements by theme. Thus, we will first see how respondents have generally taken this notion, have singled it out. Then, we will look at how they perceive the reforms that have been implemented since 2007 . These representations are often critical, in part because of the continuation of extractivism and the vicious circle of oil revenue. We will therefore discuss stakeholder links between the government and the oil rent. Finally, we will discuss the issues of what Ecuador could loose or gain by the transition between the two models defined by the respondents.

\subsection{The adoption of the concept of buen vivir by stakeholders}

Given the different answers given on the first theme, we can see that the definition of the buen vivir of the different stakeholders is closer to the culturalist and ecological approach of the notion and less to the social-statist approach. This divergence corresponds to the one between individuals that are critical to public policies implemented and those who defend them. The first group of individuals emphasizes the subjective dimension of buen vivir and its link with the natural environment.

The second group, without completely setting aside the cultural anchoring of the notion, further emphasizes access to basic necessities. There are several times the term dignified or worthy life within speech, like this excerpt:

An official in a ministry:

"We do not need a lot of things to live in dignity. Then, from this conception, the buen vivir is to optimize, from the economic point of view, the management of scarce resources, the management of these resources so that they are not resources for some and exaggerated for others but are equitably distributed." The key elements that determine the sensitivity of the actors towards one approach or another come back on the one hand to the relationship with Nature, that is to say that the described buen vivir often suggests a conversationalist approach of the environment as well as certain spirituality or subjective well-being by evoking it, and on the other hand a concern for equity and inclusion of the most marginalized populations.

\subsection{Buen vivir: a real political proposition?}

On the sample of the interviewed people, one finds people mainly critical of the policies of buen vivir implemented, rather positive individuals and who underline the progress which has been made on the last decade and people totally indifferent to the political sphere.

Critical interviewees can be divided into two sub-categories.

On the one hand, there are individuals from the political opposition or from the private sector who defend economic interests and criticize state interventionism in both trade and politics. Thus, one of the actors working in a sector of export of the raw materials informs us that the state regulation of the businesses is too important with regard to the cost of the work and of the investment and the regulation of the sectors of activity, as we note from an excerpt from his interview: 
An actor of the exportations of raw materials:

"The export is very, very difficult. Legislation is one of the reasons. Being able to start a business, develop a business, reach a competitive point of interest, everything is very, very difficult in Ecuador. In other words, if you have \$100,000 saved on a savings account and you have the opportunity to invest in Ecuador or Colombia, I would say 80\% of the time you would prefer to go to Colombia. "

Individuals disappointed by the reforms implemented under the presidency of Rafael Correa underline both the immobility of the government in the face of certain strategic choices, like the Yasuni ITT project, the inconsistencies present in speeches and political facts and the growing gap between the initial project and the public policies that followed. They are often individuals who have felt hope or participated in the initial buen vivir project. As this excerpt points out, there would have been a break in the political line:

Opposition member of a leftist party:

"That was quickly swept away, that's why in fact, from the point of view of buen vivir, very quickly, the concept has been instrumentalised and turned into a kind of speech of legitimization of all types of productive activities or public policies that ultimately were part of a continuity"

Researcher in Social Sciences:

'It's more a speech emptied of its meaning. So you have the constitution, and then you have a law of overeating, a law of the popular economy and solidarity, which show the good intentions of the state in favor of social organizations or the most excluded. You read the laws and they seem interesting because they say beautiful things but, in 2012, the government shows its most extractivist face. Then you have a law on mines, et cetera. And it breaks."

The perception of Ecuadorian public policies is tainted by major projects whose inconsistency and / or failure are emphasized several times in the interviews.

This is the case of the Yachay project, a university complex dedicated to research and "bio-knowledge", whose representations are very negative. Often described as a "white elephant", Yachay would be very badly located and very impractical. Another highly controversial project is "Millennium Schools", which has resulted in a vast program of public investment in the creation of large, centralized educational structures. This public policy is widely discussed in the rural areas as centralization has resulted in the closure of many smaller schools closer to the local population. It has greatly prolonged children's journeys between home and school without systematic transportation for this purpose. In addition, several times in the interviews, we were told a story about a sexual assault on a child on the path home / school millennium. This fact taints representations of this public investment. In addition, these centralized educational structures are dedicated to more general teachings and are given in Spanish, in contrast to small structures that took more account of cultural specificities. Thus, the interviewees believe that much public money is wasted on projects that are not efficient or that run counter to the initial inclusive political discourse.

Among those interviewed, there are also individuals with good representations of the public policies implemented. They are mainly people from the public sector and directly involved in the definition and implementation of government projects. Despite persistent oil exploitation, they point to the improvements in education, health and communication during the last years. Overall, they argue that the exit from extractivism is necessary but in the short term it allows the financing of the reduction of poverty 
indicators and the modification of the productive structure. A previous decision-maker says that the problem is not oil extraction but rather the process of accumulation of wealth that is bypassed by external elements: trade negotiations and the interest of the debt.

Finally, buen vivir's literature defines the latter as a project "under construction" (Acosta, 2014). An interview with a former member of the government describes the process of institutionalization of buen vivir as the grouping of "aspirations" of different social struggles within the Ecuadorian Constitution, which in a way defines the Constitution as a whole. Of aspirations of a society and not as a set of normative rules that structure the reforms. In this configuration, the constitutional rights defined in the Constitution may not be perceived as an imperative but rather as an ideal towards which Ecuadorian society should strive.

\subsection{Representations of the challenges of the implementation of buen vivir in Ecuador}

The stakes defined by the stakeholders of buen vivir and the extractive model are multiple and depend on the profile of the interviewee.

The issue of structural change has naturally been raised, particularly by stakeholders with a more "economic" profile. The key sectors to which Ecuador could turn are mainly processed raw materials, tourism and "bio-knowledge". Stakeholders have repeatedly mentioned the lack of industrial fabric that would have allowed the processing of raw materials. To illustrate this, several individuals have described the paradox of cocoa. As a key export sector, cocoa is sold in raw form and imported processed, mainly from the United States. The bio-knowledge sector is mentioned only by "pro-Correa" individuals. Another issue raised is that of the institutional reforms essential for the proper implementation of buen vivir. The initial project wanted a horizontal and more participative organization. Instead, the interviewees discussed the highly vertical structure of the political system, leaving room for the executive to become increasingly important and putting aside civil society and more specifically indigenous communities.

Social Science Researcher:

'It must be an interventionism that is based on, let's say, a democracy that is more precisely on the model of community democracy in the Ecuadorian countryside. We have initiatives of governments that have worked with democracies that work with many assemblies, it is much less productive, we spend more time and energy to negotiate to negotiate but at least we still have an organization. which is much less vertical and much less vulnerable to imposition of a logic that comes from above, and comes from a power that is foreign to the country."

Finally, the theme of education has come up several times. A person close to the former government mentions the "necessary" change of the "cognitive matrix". The concept of "matrix" is the fruit of a strategy of political communication that adapts itself to several contexts and that one finds regularly within the plans of planning: "productive matrix" to designate the productive structure or "cultural matrix which evokes the cultural base of the country. Here, the change in the cognitive matrix is translated "from anthropocentrism to biocentrism, from capitalism to the social and solidarity economy, from representative democracy to more deliberative, participative and community democracy, from patriarchy to feminism". This point echoes another interview by a 
researcher, who is more critical of buen vivir's policies, confiding to us that the population was not quite ready to change its habits structurally, especially on the question of environmental protection. Education has also been defined as a major factor for the issue of structural change by "pro-government".

\section{Conclusions}

This article is exploratory and tries to define the stakes of the implementation of buen vivir in Ecuador. Semi-structured interviews among the stakeholders of the political project allowed us to define some of them. As the scientific literature suggests, the first issue is primarily conceptual. The polysemous nature of the notion leaves room for different interpretations of the buen vivir and makes difficult to conceiving of a common project. The talks converge towards a vision closer to the ecologist and culturalist approach than the one adopted by the government. This is strongly supported by a very critical vision of the policies implemented since 2007 in Ecuador. These individuals emphasize the gap between the theoretical notion and the reforms implemented by the government. They discuss the intensification of oil exploitation and the concentration of power around the government of Rafael Correa. Stakeholders linked to different public administrations highlight the social progress made in recent years and justify deficiencies by external elements. The stakeholders highlighted several issues, among these, three were the most mentioned. Naturally, the first of them is the economic diversification which is difficult to consolidate. By advocating the exit from the extractivism, the Ecuadorian government has finally intensified the extraction of resources. Agreements with China involving a "pre-sale" of barrels of oil extracted from park of Yasuni require extraction until 2022. The key and potential cited sectors are often tourism and agribusiness. Another challenge, stemming from the negative perception of public policies, is the institutional challenge and the need for greater control over the executive, in order to prevent all forms of corruption as well as the waste of public resources. Finally, the education channel, particularly through greener practices, was mentioned regularly. Better funding and better education would be a way for the stakeholders to make the Ecuadorian model more sustainable in a multidimensional way.

\section{References}

Acosta, A., Martinez, E., 2011, La Naturaleza con derechos, de la filosofia a la politica, Ed. Abya Yala - Universidad politecnica salesiana, Quito.

Acosta, A., 2014, Le Buen vivir, pour imaginer d'autres mondes, Ed. Utopia, Paris.

Acosta, A., Gudynas, E., La renovación de la crítica al desarrollo y el buen vivir como alternativa, Utopia y Praxis latinoamericana-Revista Internacional de Filosofía Iberoamericana y teoría social , 53, 71-83

Arsel, M., Hogenboom, B., Pelligrini, L., 2016, The extractive imperative in Latin America, The extractive industries and society, $\mathrm{n}^{\circ} 3, \mathrm{pp} 880-887$

Beling, A.E, Vanhulst, J., Demaria, D., Rabi, V., Carballo, A.E., Pelenc, J., 2018, Discursive synergies for a 'Great Transformation' towards sustainability: pragmatic contributions to a necessary dialogue between human development, degrowth and buen vivir, Ecological Economics, 144, 304-313

Berthier, N., 2000, Les techniques d'enquêtes en sciences sociales, Ed. Armand Colin, Paris

World Commission on Environment and Development (1987), Brundtland Report, Our common future 
Bulte, E., Damania, R., Deacon, R., 2005, Resource Intensity, Institutions and Development, World Development, vol. 33, nº 7 , pp1029-1044

CEPAL, 2012, Structural change for equality, CEPAL, Santiago.

Corden W. M., 1984, Booming sector and dutch disease economics: survey and consolidation, Oxford Economic Papers, vol. 36, pp. 359-380.

Cubillo-Guevara, A.P., Hidalgo-Capitán, A.L., García-Álvarez, S. (2016). El Buen Vivir como alternativa al desarrollo para América Latina. Iberoamerican Journal of Development Studies, 5(2):30-57

Ebeke, C., Omgba, L., Laajaj, R., 2015, Oil, governance and the (mis)allocation of talent in developing countries, Journal of Development Economics, $\mathrm{n}^{\circ} 114$, pp 126-141.

Fenneteau H., 2007, Les techniques d'enquête : entretien et questionnaire, Collection « Les Topos » 2ème édition, Dunod, Paris.

Fontaine, G., 2008, Le mouvement écologiste contre l'exploitation d'hydrocarbures en Équateur, Problèmes d'Amérique latine, n 70, pp. 41-60.

Guardiola, J., et Garcia-Quero, F., 2014, Buen Vivir (living well) in Ecuador: Community and environmental satisfaction without household material prosperity?,Ecological Economics, n¹07, pp 177-184

Gudynas, E., 2011a, Buen Vivir : today's tomorrow, Development, 54(4), pp441-447

Gudynas, E., 2011b. Caminos para las transiciones post extractivistas, in Alayza, A., Gudynas, E., 2011, Transiciones. Post extractivismo y alternativas al extractivismo en Peru. RedGE y CEPES, Lima, pp. 187216.

Gudynas, E., 2011c, Desarrollo, extractivismo y buen vivir. Debates sobre el desarrollo y sus alternativas en America Latina: Una breve guia heterodoxa." In Lang, M., Mokrani, D., 2011, Mas alla del desarrollo, Abya Yala, Quito, pp 21-54.

Gudynas, E., 2011d, Tensiones, contradicciones y oportunidades de la dimension ambiental del buen vivir, in Farah I.H.,Vasapollo, L., 2011, Vivir bien: ¿Paradigma no capitalista?, CIDES - UMSA y Plura, La Paz, pp231-246

Gudynas, E., 2001e, Desarrollo, derechos de la naturaleza y buen vivir después de Montecristi, in Weber, G., 2011, Debates sobre cooperación y modelos de desarrollo. Perspectivas desde la sociedad civil en el Ecuador, Ed. Centro de Investigaciones CIUDAD y Observatorio de la cooperación al desarrollo, Quito

Gylfason, T., 2001, Natural resources, education and economic development, European Economic Review, n 45 , pp 847-859

Hidalgo-Capitán, A.L., Cubillo-Guevara, A.P., 2014. Seis debates abiertos sobre el sumak kawsay. ÍCONOS 48, 25-40.

Huanacuni Mamani, F., 2010, Buen Vivir / Vivir Bien. Filosofia, politicas, estrategias y experiencias regionales andinas, Ed. Coordinadora Andina de Organizaciones Indígenas (CAOI), La Paz

Huntington, H., 2000, Using traditional ecological knowledge in science: methods and applications, Ecological Applications, vol 10, $\mathrm{n}^{\circ} 5$, pp1270-1274

Khotari, A., Demaria, F., Acosta, A., 2014, Buen Vivir, Degrowth and Ecological Swaraj: Alternatives to sustainable development and the Green Economy, Development, n57, pp362-375

Larrea, C., 2013, Extractivism, economic diversification and prospects for sustainable development in Ecuador. Ed: UASB Digital, Quito

Le-Quang, M., Vercoutere, T., 2013. Ecosocialismo y Buen Vivir. Diálogo entre dos alternativas al capitalismo. Ed: IAEN, Quito.

Mehlum, H., Moene, K., Torvik, R., 2006. Institutions and the resource curse. Economic Journal, vol 116, $\mathrm{n}^{\circ} 508, \mathrm{pp} 1-20$.

Ponce, J. and Vos, R., 2012, Redistribution without Structural Change in Ecuador. Rising and Falling Income Inequality in the 1990s and 2000s, UNU-WIDER Working Paper

Purcell,T., Fernández, N., Martinez, E., 2017, Rents, knowledge and neo-structuralism: transforming the productive matrix in Ecuador, Third World Q. 38(4) 918-938

Radcliffe, S., 2012, Development for a postneoliberal era ? Sumak kawsay, living well and the limits to decolonisation in Ecuador, Geo forum, n 43, pp 240-249

Robinson, J. A., Torvik, R. and Verdier, T. (2002). Political foundations of the resource curse, Journal of Development Economics, vol79, n², pp 447-468

Robinson, J.A., Torvik, R., 2005, Withe elephants, Journal of public economics, n89, pp197-210

Ross, M., 2001, Does oil hinder democracy? World Politics, n53, p325-361

Rostow, W.., 1959, The stages of economic growth, Economic History Revue, vol 12, pp 1-16 
Sachs, J., Warner, A., 1995. Natural resource abundance and economic growth, NBER Working Paper No. 5398.

SENPLADES, 2009, Recuperación del Estado nacional para alcanzar el buen vivir. 2007-2009, Quito: Senplades

SENPLADES, 2013, Plan Nacional de Desarrollo/Plan Nacional de Buen Vivir 2013- 2017, Quito: SENPLADES.

Stijns, J.P, 2005, Natural Resource Abundance and economic growth revisited, Resources Policy, n³0, p 107130

Villalba, C.U., Etxano, I., 2017, Buen Vivir vs Development (II): The Limits of (Neo)Extractivism, Ecological Economics, 138, 1-11

Van Der Ploeg, F., 2011, Natural Resources : curse or blessing, ?, Journal of Economic literature, vol49, $\mathrm{n}^{\circ} 2$, pp366-420

Vanhulst, J., Beling, A.E, 2013, Buen vivir et développement durable : rupture ou continuité ?, Ecologie \& politique 2013, n 46 , pp 41-54.

Vanhulst, J., Beling, A.E., 2014, Emergent discourse within or beyond sustainable development, Ecological Economics, 101, pp 54-63

Van Teijlingen, K, 2016, the will to improve at the mining frontier : neo-extractivism, development and governmentality in the ecuadorian Amazon, The extractive industries and society, $\mathrm{n}^{\circ} 3$, pp $902-911$

Viteri Gualinga, C., 2002. Visión indígena del desarrollo en la Amazonía. Polis. Disponible en ligne: http://bit.ly/1cZ2595, consulté le 09 Avril 2019

Walsh, C., 2010, Development as Buen Vivir : Institutional arrangements and (de)colonial entanglements, Development, $\mathrm{n}^{\circ} 53$, pp $15-21$

Walsh, C., 2012, Afro and Indigenous life-visions in/and politics. (De)colonial perspectives in Bolivia and Ecuador, Bolivian studies journal, vol 18, pp 49-69 